\title{
Analysis of the prevalence of polymorphisms in the glutathione $S$ transferase gene (GST) in cataract patients from Goiânia
}

\author{
I.R. Costa ${ }^{1,3}$, R.S. Mascarenhas ${ }^{3}$, J.F. Corrêa ${ }^{3}$, F.R.B. Oliveira ${ }^{3}$, \\ S.G. Fernandes ${ }^{3}$, F.O. Souza ${ }^{3}$, G.M. dos Reis ${ }^{3}$, A. de P.R. Júnior ${ }^{3}$, \\ D.A. Rodrigues ${ }^{2}$, J.V.M. Martins ${ }^{2}$, K.S.F. e Silva ${ }^{4}$ and K.K.V.O. Moura ${ }^{1,2,3}$ \\ ${ }^{1}$ Departamento de Biotecnologia e Biodiversidade da Rede Pró Centro-Oeste, \\ Universidade Federal de Goiás, Goiânia, GO, Brasil \\ ${ }^{2}$ Núcleo de Pesquisas Replicon, Pontifícia Universidade Católica de Goiás, \\ Goiânia, GO, Brasil \\ ${ }^{3}$ Departamento de Biomedicina, Pontifícia Universidade Católica de Goiás, \\ Goiânia, GO, Brasil \\ ${ }^{4}$ Laboratório de Genética e Biologia Molecular, Universidade Federal de Goiás, \\ Goiânia, GO, Brasil
}

Corresponding author: K.S.F. de Silva

E-mail: smallbinho@hotmail.com

Genet. Mol. Res. 15 (3): gmr. 15038050

Received November 12, 2015

Accepted June 14, 2016

Published August 26, 2016

DOI http://dx.doi.org/10.4238/gmr. 15038050

Copyright (C) 2016 The Authors. This is an open-access article distributed under the terms of the Creative Commons Attribution ShareAlike (CC BY-SA) 4.0 License.

\begin{abstract}
The aim of this study was to determine the prevalence of polymorphisms in the glutathione S-transferase genes GSTM1 and GSTT1 in patients with lens opacity (cataract). Peripheral blood samples were obtained from male and female patients $(\mathrm{N}=23)$ with cataract. The GSTM1 and GSTT1 polymorphic regions were amplified by polymerase chain reaction, and the amplification products were electrophoresed on a $2 \%$ agarose gel. The obtained bands were visualized
\end{abstract}


by staining with ethidium bromide. The results were compared by a chi-square test using the BioEstat software (v.5.0). The frequencies of the GSTM1- and GSTT1-null genotypes were higher than those of the GSTM1- and GSTT1-present genotypes. The frequency of GSTT1-null genotypes was approximately 1.7 times higher than that of GSTM1, which was a statistically significant difference $(\mathrm{P}=0.0019)$. Although a consensus remains to be reached on the correlation between genetic polymorphisms in GSTs and cataract susceptibility, the observations from most scientific studies are similar to those reported in this study. Thus, we conclude that the absence of these genes, particularly GSTT1, is correlated with the development of lens opacity.

Key words: Cataract; GSTM1; GSTT1; Polymorphism

\section{INTRODUCTION}

The term cataract is used to designate any clouding of the lens that can lead to blindness (Snellingen et al., 2002). An estimated 17 million people worldwide are believed to have lost their sight because of this anomaly (Kara-José and Temporini, 2002). Approximately 600,000 Brazilians were reportedly blinded by this disease in 1998; the cataract was surgically removed in approximately $95 \%$ of these cases, according to the Brazilian Council of Ophthalmology (CBO) (Gomes et al., 2008). Developing countries such as Brazil have reduced access to eye care leading to a decrease in individuals' health and quality of life and making them susceptible to eye diseases (Kara-José Junior and Cursino, 2004; Gomes et al., 2008).

Cataract can be classified as a genetic, congenital, or acquired disease; cataract can also be categorized as an early- or late-onset (including age-related onset) disease (Snellingen et al., 2002). Cataract can be induced by several risk factors, including metabolic diseases such as diabetes, galactosemy, hypocalcemia, and hyperthyroidism, kidney disease, steroid usage, toxicity induced by cigarette usage or alcohol consumption, trauma, radiation, eye disease, pregnancy-related infections such as toxoplasmosis or rubella, or malnutrition (Congdon, 2001). Individuals with chromosomal abnormalities such as those in Down syndrome, Patau syndrome, or Edward syndrome may also develop this disease, but with different signs and symptoms (Rojas et al., 2005). Traumatic cataract is the major cause of unilateral blindness in the youth (Couto Junior and Moura, 2004); however, the causative trauma need not necessarily be blunt or penetrating (Pereira et al., 2012).

The major risk factors for congenital cataract include metabolic disorders, intrauterine infections, and genetic syndromes (Wirth et al., 2002); childhood cataract is another type of congenital cataract, as these same factors are responsible for the genesis of crystalline opacities that appear at birth or during early childhood (early onset of the disease) (Cruz et al., 2005). Its infectious origin often makes it impossible to perform early surgery, as it can induce systemic and ocular anomalies (Kara-José Junior and Cursino, 2004).

Lens opacity damages the light diffractive ability of the lens; therefore, it is a primary cause of impaired vision in the elderly. Cloudy vision, decreased visual acuity, increased light sensitivity, color vision disturbance, decreased depth perception, and frequent change in refraction are some of the frequent complaints of the elderly (Camelo et al., 2009).

Oxidative stress and antioxidant systems are extremely important for ocular tissues.

Genetics and Molecular Research 15 (3): gmr.15038050 
Ocular tissues regenerate slowly, allowing accumulation of toxins that cause tissue damage to the ocular tissue; this, in turn, could lead to molecular changes that contribute to the development of glaucoma, cataract, and age-related diseases (Yildirim et al., 2005). One such toxic factor is the reactive oxygen species (ROS); however, its toxicity can be mitigated by the action of ROS-specific enzymes, which convert ROS to hydrophilic compounds, thereby facilitating their elimination from the body (Silva, 2012).

Glutathione S transferases (GSTs) are fundamental components of the cellular detoxification system, and play a major role in ROS accumulation-induced oxidative stress (Yildirim et al., 2005). Cellular oxidative stress is a biological condition that results in an imbalance between the production of ROS and their detoxification by biological processes (that remove or repair the damage they cause) (Schafer and Buettner, 2001).

GSTs are currently divided into six classes: $\alpha, \mu, \pi, \theta, \Omega$, and Z (Ferreira and Rocha, 2005). Genes coding for the $\mu$ (GSTM1) and $\theta$ (GSTT1) classes of GSTs are associated with several diseases. GSTM1 and GSTT1 are polymorphic in humans, and the homozygous forms of both genes are absent or deleted in $40-50 \%$ (GSTM1) or 16-24\% (GSTT1) of various ethnic populations (Silva, 2012). Previous epidemiological studies have demonstrated the correlation of these polymorphisms with eye diseases (Yildirim et al., 2005).

GSTM1 is located on chromosome 1 at p13.1, and consists of two functional alleles: GSTM-1A and GSTM-1B, which differ by the substitution of a single base pair (Cotton et al., 2000); an additional allele of this gene with null activity is obtained by deletion of a base pair $(G S T M 1 * 0)$. The encoded proteins GSTM1-A and GSTM1-B, by the genes with functional alleles, present lysine and asparagine at position 172, respectively. However, both proteins have the same detoxification efficacy.

GSTT1 is located on chromosome 22 at position q11.13; this gene contains two alleles, allele A present $\left(G S T T 1^{*} 1\right)$ and a zero allele $\left(G S T T 1^{*} 0\right)$. Previous studies have indicated that $G S T T 1^{*} 0$ is responsible for the total or partial suppression of the gene, inducing a deficiency in the activity of the enzyme, which is directly related to the detoxification process (Silva, 2012). Therefore, the aim of this study was to determine the prevalence of polymorphisms in GSTM1 and GSTT1 in patients with cataract, to establish a correlation between these variant forms and its pathogenesis.

\section{MATERIAL AND METHODS}

This study was approved by a formally constituted research Ethics Committee at the Catholic University of Goiás.

Peripheral blood samples were collected from 23 patients with cataract (males and females, $>18$ years of age) who visited the Goiânia Eye Institute. DNA was extracted from all samples using the Mini Spin kit (Kasvi ${ }^{\circledR}$, Curitiba, PR, Brazil), at the Replicon Research Core Laboratory, Catholic University of Goiás. The extracted DNA was amplified by polymerase chain reaction (PCR) to detect polymorphisms in GSTM1 and GSTT1.

The null and present genotypes were defined when the target genes were not amplified in the patients and when at least one allele was amplified, respectively. The primer sequences used to detect polymorphisms in GSTM1 and GSTT1 were as follows: 5'-ACC CCA GGG CTC TAT GGG AA-3' (forward) and 5'-TGA GGG CAC AAG AAG CCC TT-3' (reverse; 216-bp fragment) (Bell et al., 1993), and 5'-TTC CTT ACT GGT CCT CAC ATC TC-3' (forward) and 5'-TCA CCG GAT CAT GGC CAG CA-3' (reverse; 480-bp fragment), respectively (Pemble

Genetics and Molecular Research 15 (3): gmr.15038050 
et al., 1994). The PCR products were electrophoresed on a $2 \%$ agarose gel, stained with $5 \mu \mathrm{g} /$ $\mathrm{mL}$ ethidium bromide, and visualized on a video documentation system (VDS; Amersham Biosciences). The results were statistically compared by a chi-square test using the BioEstat software (v.5.0; biocistron.blogspot.com/).

\section{RESULTS}

GSTM1 expression was observed in 43\% (10/23) of the analyzed cataract patients; the remaining $(13 / 23 ; 57 \%)$ expressed the null genotype (GSTM1-null). However, GSTT1 expression was observed in a very small percentage of the sample population $(1 / 23 ; 4 \%)$; that is, GSTT1 was not expressed (zero GSTT1) in $96 \%(22 / 23)$ of the sample population. The frequencies of the null GSTM1 and GSTT1 genotypes were higher than those of the present genotypes; moreover, the frequency of GSTT1-null genotype was approximately 1.7 times higher than that of GSTM1, a statistically significant difference $(P=0.0019)$. Individual analysis of the GST genes revealed that GSTT1 expression was predominantly (significantly) absent in patients with cataract, compared to the expected values in the population $(\mathrm{P}<0.0001$; Table 1$)$.

Table 1. Distribution of glutathione S-transferase genes GSTM1 and GSTT1 in cataract patients.

\begin{tabular}{l|c|c|c|c|c}
\hline \multirow{2}{*}{ Genotype } & \multicolumn{2}{|c|}{ GSTM1** } & \multicolumn{2}{|c}{ GSTT1*** } & \multirow{2}{*}{$\mathrm{P}^{*}$} \\
\cline { 2 - 6 } & $\mathrm{N}$ & $\%$ & $\mathrm{~N}$ & $\%$ & \\
\hline Present & 10 & $43 \%$ & 1 & $4 \%$ & 0.0019 \\
\hline Null & 13 & $57 \%$ & 22 & $96 \%$ & \\
\hline Total & 23 & $100 \%$ & 23 & $100 \%$ & \\
\hline
\end{tabular}

${ }^{*}$ Chi-square test. $* * \mathrm{P}=0.6767$ (chi-square test). ${ }^{* * *} \mathrm{P}<0.0001$ (chi-square test).

\section{DISCUSSION}

Cataract is a major public health concern, because of its high prevalence in the population. This can be explained by the process of aging in the population, resulting in senile and age-related cataract. A study on ocular diseases from Rio Grande do Sul shows that approximately $80 \%$ of the population older than 80 years present anomalies in at least one eye. Subsequent studies conducted in Finland, Barbados, USA, and England reported similar results (Romani, 2005).

Our results were corroborated by another study conducted in 2007, which reported that $91.8 \%$ of all patients who underwent cataract surgery (in 2007) were over 50 years old, with females showing greater susceptibility to cataract $(60.1 \%)$. These results were also corroborated by epidemiological studies conducted in São Paulo and Pernambuco. The increased life expectancy of the population may lead to a higher incidence of cataract in older adults (Romani, 2005; Gomes et al., 2008).

The pathophysiology of cataract development remains to be understood. Several genetic polymorphisms and environmental factors have been previously designated as predisposing factors for cataract (Sireesha et al., 2012). An in-depth literature review on PubMed resulted in the identification of several genes related to congenital (CRY, GIA3, AQPO, and MIP) and age-related (GSTT1/M1, EphA2, and CRYAA) cataract development (Cazorla, 2015).

Polymorphisms in GST genes are characterized by their total deletion, leading to the complete lack of glutathione $\mathrm{S}$ transferase activity in individuals; this is a causative feature of several diseases, including those that affect the vision. In this study, 57\% of

Genetics and Molecular Research 15 (3): gmr.15038050 
all cataract patients were shown to express the GSTM1-null genotype, which was within the expected range (20-70\%). The absence of GSTT1 in patients with cataract, as seen in previous studies (11-38\%), was significantly different from that seen in our study (96\%) (Reis et al., 2011).

Çelikk et al. (2015) reported a statistically significant prevalence of GSTMI polymorphism in patients with cataracts $(\mathrm{P}=0.8620)$, compared to that seen in this study. Their results confirmed a link between this disease and the null GSTM1 polymorphism. However, a comparison of the case group in this study with the case and control groups reported by Çelikk et al. (2015) with respect to the GSTT1 polymorphisms showed very different results $(\mathrm{P}<0.001)$, suggesting a correlation between the null GSTT1 polymorphism and the development of cataract. Our study was also corroborated by a previous study conducted by Chandra et al. (2016) in northern India, who reported that the GSTM1 and GSTT1 polymorphisms were associated with increased risk of cataract development. Further, Saadat et al. (2012) reported that the GSTM1-null genotype increased the risk of developing this pathology in an Iranian population. These results are similar to those found in this study $(\mathrm{P}=0.9558)$. However, they found no correlation between the GSTT1null genotype and cataract, which is a significant difference from the results seen in this study $(\mathrm{P}<0.001)$.

In contrast, other studies conducted in Chinese and Indian populations reported a correlation between the presence of GSTM1 and the absence of GSTT1 and the development of senile cortical cataract, which conflicts with our results (Juronen et al., 2000; Saadat et al., 2012). Sun et al. (2010) attempted to identify a correlation between the absence of GSTM1 and GSTT1 and senile cataract in Asians, and not in Caucasians, via a meta-analysis. They have found that the relationship between GSTM1-null genotype and risk for senile cataract is not statistically significant. Previous studies have shown that the development of diseases by genetic predisposition is correlated to the ethnic background of the patient. The Brazilian population has a high degree of miscegenation; this could account for the variation in cataract risk, compared to that observed in pure ethnicities.

\section{CONCLUSIONS}

Although a consensus remains to be reached regarding the correlation between genetic polymorphisms in GSTs and cataract susceptibility, the observations of a majority of the scientific studies are similar to those reported in this study. Therefore, we conclude that the absence of these genes, particularly GSTT1, is correlated with the development of lens opacity.

\section{Conflicts of interest}

The authors declare no conflict of interest.

\section{ACKNOWLEDGMENTS}

We would like to thank the Pontifical Catholic University of Goiás, Goiânia, Brazil (Replicon / Prope / MGene / FAPEG / CNPq) to have contributed and supported this research.

Genetics and Molecular Research 15 (3): gmr.15038050 


\section{REFERENCES}

Bell DA, Taylor JA, Paulson DF, Robertson CN, et al. (1993). Genetic risk and carcinogen exposure: a common inherited defect of the carcinogen-metabolism gene glutathione S-transferase M1 (GSTM1) that increases susceptibility to bladder cancer. J. Natl. Cancer Inst. 85: 1159-1164. http://dx.doi.org/10.1093/jnci/85.14.1159

Camelo J, Sales PCD, Castro ANBV, Pereira LSM, et al. (2009). Correlação entre acuidade visual e desempenho funcional em idosos com catarata. Geriatria Gerontol. 3: 158-163.

Cazorla FP (2015). Caracterização da produção científica sobre polimorfismos genéticos em catarata. Master's thesis, PUCGoiás, Goiânia.

Çelįk SK, Aras N, Yildirim Ö, Turan F, et al. (2015). Glutathione S-transferase GSTM 1, null genotype may be associated with susceptibility to age-related cataract. Adv. Clin. Exp. Med. 24: 113-119. http://dx.doi.org/10.17219/acem/38143

Chandra A, Raza ST, Abbas S, Singh L, et al. (2016). Polymorphism of GST and FTO genes in risk prediction of cataract among a North Indian population. Ophthalmic Genet. 37: 19-24.

Congdon NG (2001). Prevention strategies for age related cataract: present limitations and future possibilities. $\mathrm{Br}$. $J$. Ophthalmol. 85: 516-520.http://dx.doi.org/10.1136/bjo.85.5.516

Cotton SC, Sharp L, Little J and Brockton N (2000). Glutathione S-transferase polymorphisms and colorectal cancer: a HuGE review. Am. J. Epidemiol. 151: 7-32.http://dx.doi.org/10.1093/oxfordjournals.aje.a010124

Couto Junior AS and Moura EM (2004). Fratura "blow-out" da órbita. In: Trauma ocular (Freitas JA and Cardoso LM, eds.). Revinter, Rio de Janeiro.

Cruz CB, Endriss D, Ventura B and Ventura L (2005). Catarata na infância: perfil socioeconômico, gestacional e desenvolvimento neuropsicomotor. Arq. Bras. Oftalmol. 68: 9-13. http://dx.doi.org/10.1590/S000427492005000100003

Ferreira CG and Rocha JC (2005). Suscetibilidade Genética ao Câncer. In: Oncologia Molecular, Parte III: Oncogenética, 3rd edn., Atheneu Editora, 295-305.

Gomes BAF, Biancardi AL, Netto CF, Gaffree FFP, et al. (2008). Perfil socioeconômico e epidemiológico dos pacientes submetidos à cirurgia de catarata em um hospital universitário. Rev. Bras. Oftalmol. 67: 220-225.

Juronen E, Tasa G, Veromann S, Parts L, et al. (2000). Polymorphic glutathione S-transferases as genetic risk factors for senile cortical cataract in Estonians. Invest. Ophthalmol. Vis. Sci. 41: 2262-2267.

Kara-José N and Temporini ER (2002). Catarata e cegueira: epidemiologia e prevenção. In: Cristalino e catarata (Arieta CEL, eds.). Cultura Médica, Rio de Janeiro, 50-56.

Kara-José Junior N and Cursino M (2004). Whitaker E. Cirurgia de catarata: otimização de centro cirúrgico com utilização de pacote cirúrgico pré-montado. Arq. Bras. Oftalmol. 67: 305-309. http://dx.doi.org/10.1590/S000427492004000200022

Pemble S, Schroeder KR, Spencer SR, Meyer DJ, et al. (1994). Human glutathione S-transferase theta (GSTT1): cDNA cloning and the characterization of a genetic polymorphism. Biochem. J. 300: 271-276. http://dx.doi.org/10.1042/ bj3000271

Pereira RS, Krieger LA, Mariushi CA and Moreira H (2012). Perfil epidemiológico de pacientes com catarata traumática no Hospital de Olhos do Paraná. Rev. Bras. Oftalmol. 71:236-240. http://dx.doi.org/10.1590/S0034-72802012000400006

Reis AAS, Pinheiro DS, Mundim CA, Jesuíno RSA, et al. (2011). As implicações do polimorfismo genético do gene GST na patogênese do diabetes mellitus tipo 2. Rev. Univ. Vale do Rio Verde 9: 92-100. http://dx.doi.org/10.5892/ ruvrv.2011.92.92100

Rojas MVM, Chimelli LMC and Simões AL (2005). Distrofia miotônica tipo 1 em pacientes com catarata: diagnóstico molecular para triagem e aconselhamento genético. Arq. Bras. Oftalmol. 68: 15-20.http://dx.doi.org/10.1590/S000427492005000100004

Romani FA (2005). Prevalência de transtornos oculares na população de idosos residentes na cidade de Veranópolis, RS, Brasil. Arq. Bras. Oftalmol. 68: 649-655.http://dx.doi.org/10.1590/S0004-27492005000500015

Saadat I, Ahmadi Z, Farvardin-Jahromi M and Saadat M (2012). Association between cataract and genetic polymorphisms of GSTM1, GSTT1, and GSTO2 with respect of work place. Mol. Vis. 18: 1996-2000.

Schafer FQ and Buettner GR (2001). Redox environment of the cell as viewed through the redox state of the glutathione disulfide/glutathione couple. Free Radic. Biol. Med. 30: 1191-1212. http://dx.doi.org/10.1016/S0891-5849(01)00480-4

Silva CTX (2012). Análise do polimorfismo da Glutationa S-Transferase M1 e T1 em pacientes portadores de glaucoma primário de ângulo aberto. Master's thesis, PUC Goiás, Goiânia.

Sireesha R, Laxmi SG, Mamata M, Reddy PY, et al. (2012). Total activity of glutathione-S-transferase (GST) and polymorphisms of GSTM1 and GSTT1 genes conferring risk for the development of age related cataracts. Exp. Eye Res. 98: 67-74.http://dx.doi.org/10.1016/j.exer.2012.03.002

Genetics and Molecular Research 15 (3): gmr.15038050 
Snellingen T, Evans JR, Ravilla T and Foster A (2002). Surgical interventions for age-related cataract. Cochrane Database Syst. Rev. 2: CD001323.

Sun L, Xi B, Yu L, Gao XC, et al. (2010). Association of glutathione S-transferases polymorphisms (GSTM1 and GSTT1) with senile cataract: a meta-analysis. Invest. Ophthalmol. Vis. Sci. 51: 6381-6386. http://dx.doi.org/10.1167/iovs.10$\underline{5815}$

Wirth MG, Russell-Eggitt IM, Craig JE, Elder JE, et al. (2002). Aetiology of congenital and paediatric cataract in an Australian population. Br. J. Ophthalmol. 86: 782-786. http://dx.doi.org/10.1136/bjo.86.7.782

Yildirim O, Ateş NA, Tamer L, Oz O, et al. (2005). May glutathione S-transferase M1 positive genotype afford protection against primary open-angle glaucoma? Graefes Arch. Clin. Exp. Ophthalmol. 243: 327-333.http://dx.doi.org/10.1007/ $\underline{\text { s00417-004-1013-9 }}$

Genetics and Molecular Research 15 (3): gmr.15038050 